\title{
The effect of home exercise on the posture and mobility of people with HAM/TSP: a randomized clinical trial
}

\author{
Efeitos de exercícios domiciliares sobre a postura e mobilidade de \\ pessoas com HAM/TSP: ensaio clínico randomizado \\ Renata de Sousa MOTA', Maíra Carvalho MACÊDO², Sandra CORRADIN/3,4,5, Naiane Araújo PATRÍCIO, \\ Abrahão Fontes BAPTISTA7, Katia Nunes SÁ ${ }^{4}$
}

\begin{abstract}
Background: Physical therapy has positive results in people with tropical spastic paraparesis (TSP). However, mobility and distance from rehabilitation centers limit the participation in outpatient programs. Objective: To evaluate the impact of a home exercise program on the posture and functional mobility of people with TSP. Methods: A randomized controlled trial comparing three groups of people who performed guided exercises from a guidebook for six months: supervised (SG), unsupervised (WG), and control (CG). Primary outcomes: postural angles $\left(\mathrm{SAPO}^{\circledR}\right.$ ) and functional mobility (TUG). Secondary outcomes: gait parameters (CVMob ${ }^{\circledR}$ ). Results: The protocol described in the guidebook improved postural angles and functional mobility. There were also positive gait parameter effects ( $p<0.05)$. SG presented better responses than WG did, but both were preferable to CG. Conclusion: Home exercises oriented by a guidebook may benefit posture, functional mobility and gait parameters in people with TSP, and physiotherapist supervision can ensure better results.
\end{abstract}

Keywords: tropical spastic paraparesis; home exercise; posture; functional mobility; gait.

\section{RESUMO}

Introdução: A fisioterapia apresenta resultados positivos em pessoas com paraparesia espástica tropical (PET). Entretanto, a dificuldade de locomoção e a distância dos centros de reabilitação limitam a participação em programas ambulatoriais. Objetivo: Avaliar o impacto de um programa de exercícios domiciliares na postura e mobilidade funcional de pessoas com PET. Métodos: Um ensaio clínico randomizado comparou três grupos de pessoas que realizaram exercícios guiados por cartilha: com supervisão (GS), sem supervisão (GN) e controle (GC) durante seis meses. Desfechos primários: ângulos posturais (SAPO ${ }^{\circledR}$ ) e mobilidade funcional (TUG). Desfechos secundários: parâmetros da marcha $\left(\mathrm{CVMob}^{\circledR}\right)$. Resultados: O protocolo descrito na cartilha melhorou os ângulos posturais e a mobilidade funcional. Os resultados também foram positivos para os parâmetros da marcha ( $p<0,05)$. O GS apresentou melhores respostas que o GN, porém ambos foram preferiveis ao GC. Conclusão: Exercícios domiciliares orientados por cartilha podem ser úteis para beneficiar a postura, mobilidade funcional e parâmetros de marcha em pessoas com PET, e a supervisão do fisioterapeuta possibilita garantir melhores resultados.

Palavras-chave: paraparesia espástica tropical; exercício domiciliar; postura; mobilidade funcional; marcha.

The retrovirus human T-cell lymphotropic virus type 1 (HTLV-1) infects approximately 10 million people worldwide $^{1}$. In Brazil, Salvador City (Bahia State) has the highest prevalence of HTLV-12. A total of 3-5\% of people infected with HTLV-1 develop tropical spastic paraparesis or
HTLV-1-associated myelopathy (HAM/TSP) around their fourth decade of life ${ }^{3}$. Women with less schooling and at low socioeconomic levels are the most affected ${ }^{3}$. HAM/TSP is a chronic, degenerative and progressive inflammatory process that affects the spinal cord, especially the thoracic

${ }^{1}$ Universidade Federal do Recôncavo da Bahia, Centro de Ciência e Tecnologia em Energia e Sustentabilidade, Feira de Santana BA, Brazil.

${ }^{2}$ Instituto do Cérebro - Fundação para Neurologia e Neurocirurgia, Salvador BA, Brazil.

${ }^{3}$ Universidade de Campinas, Campinas SP, Brazil.

¿Escola Bahiana de Medicina e Saúde Pública, Departamento de Fisioterapia, Salvador BA, Brazil.

5Universidade Federal da Bahia, Salvador BA, Brazil.

${ }^{6}$ Escola Bahiana de Medicina e Saúde Pública, Departamento de Tecnologias de Saúde, Salvador BA, Brazil.

${ }^{7}$ Universidade Federal do ABC, Centro de Matemática, Computação e Cognição, São Paulo SP, Brazil.

Renata de Sousa MOTA iD https://orcid.org/0000-0002-5176-3329; Maíra Carvalho MACÊDO iD https://orcid.org/0000-0002-8470-5838; Sandra CORRADINI (iD https://orcid.org/0000-0003-2101-0091; Naiane Araújo PATRÍCIO iD https://orcid.org/0000-0002-9616-0898;

Abrahão Fontes BAPTISTA (iD) https://orcid.org/0000-0001-7870-3820; Katia Nunes SÁ iD https://orcid.org/0000-0002-0255-4379

Correspondence: Renata de Sousa Mota; Centro de Ciência e Tecnologia em Energia e Sustentabilidade (CETENS), Universidade Federal do Recôncavo da Bahia (UFRB), Av. Centenário, 697; 44042-280 Feira de Santana BA, Brazil; E-mail: renatasmota@gmail.com

Conflict of interest: There is no conflict of interest to declare.

Received on October 25, 2018; Received in its final form on August 31, 2019; Accepted on October 18, 2019. 
region, and causes demyelination and reduced sensorimotor capacity ${ }^{4}$.

The most common symptoms are lower limb muscle weakness, hyperreflexia, hypertonia, pelvic floor dysfunction and moderate-to-severe pain ${ }^{5,6}$. These symptoms cause postural $^{7}$, locomotive ${ }^{8}$ and balance ${ }^{9}$ changes, all of which affect mobility and cause frequent falls. The impact on functional mobility occurs between two and five years after the initial symptom onset, and one in every five symptomatic individuals progresses to the wheelchair in a 10 -year period ${ }^{8}$. This picture evolves to physical dependence, reduction of social participation and productive incapacity, all of which cause significant suffering and high costs ${ }^{3}$.

Exercises to improve functional performance have been suggested, because they present positive results in mobility ${ }^{8,10,11}$. A Pilates protocol improved cervical and trunk alignment, varus knee and knee flexion ${ }^{12}$ and pain intensity, and positively impacted the quality of life $^{13}$. Another home exercise program increased muscle strength and length with improved quality of life $^{14}$. Proprioceptive neuromuscular facilitation $^{15}$ and functional exercises ${ }^{16}$ improved mobility and balance.

Although exercise protocols present promising results for this population, they are reduced and have not yet been tested in a clinical trial in people with HAM/TSP. Additionally, it is important to test a home exercise protocol guided by socioeducational materials on a guidebook, because this method is effective in the treatment of other chronic degenerative conditions. Furthermore, it stimulates the autonomy of individuals to deal with their disease ${ }^{17}$. In Brazil, the low socioeconomic status observed in the HAM/TSP population limits its access to outpatient programs. This situation is particularly aggravating in Bahia State, because this population, for the most part, lives within the state in regions far from rehabilitation centers, which are located in the capital city of Salvador. In view of these considerations, the hypothesis for this study was that a home exercise protocol may benefit the HAM/TSP population. Thus, the purpose of this study was to evaluate the impact of a home exercise program on the posture and functional mobility of people with HAM/TSP.

\section{METHODS}

\section{Study design/ethical aspects}

This randomized clinical trial followed the recommendations of the Consolidated Standards of Reporting Trials (CONSORT) and Resolution 466/12 of the National Health Council. The project was approved by the Ethics and Research Committee of Bahia School of Medicine and Public Health (EBMSP) and registered in the Brazilian Registry of Clinical Trials (REBEC), RBR-849jyv and UTN: U1111-1176-2858. Data were collected from January 2014 to August 2015 in
Salvador (Bahia), Brazil. The study population consisted of individuals enrolled in the Multiprofessional Assistance and Research Center for Family and Individuals with HTLV (CHTLV) of the EBMSP.

\section{Participant selection}

Recruitment occurred from CHTLV chart analysis that contained the clinical data on diagnosis and time of disease. Inclusion criteria were: people aged 18 and over; both genders; HAM/TSP diagnosis; classified as definite or probable according to World Health Organization (WHO) criteria ${ }^{18}$; capable of remaining in a static posture for 30 seconds and roaming for six meters without the use of auxiliary devices for walking. Exclusion criteria were: people affected by other rheumatic, orthopedic or neurological diseases; absence of more than $20 \%$ of the proposed exercise programme; people who presented difficulties in understanding the guidelines of the exercise programme or the used evaluation instruments.

\section{Sample size}

Sample size was calculated using the online calculator of the Laboratory of Epidemiology and Statistics of Universidade de São Paulo ${ }^{19}$, using a standard deviation of 3.24 and a difference of $3.37 \mathrm{sec}$ as parameters ${ }^{16}$ for the functional mobility measured by means of the Timed Up and Go test (TUG), between the supervised group and the control group $(\alpha \geq 0.05$; power $=80 \%$ ). A sample of 11 patients was estimated for each of the three groups. Considering the follow-up losses, three individuals were added per group, totaling 42 participants.

\section{Randomization}

Randomization was performed with the help of data entry by a researcher who did not participate in the recruitment, collection, tabulation or analysis of the data. The numbers one and two of the data allocated the participants in the supervised group (SG); the numbers three and four, in the without-supervision group (WG); and the numbers five and six, in the control group (CG).

\section{Assessment procedures}

The assessment was performed by a previously trained and blinded researcher. A single blinded physiotherapist with an 11-year experience was responsible for the intervention. Participants were identified with codes to perform data tabulation, and blinding was only broken after the statistical analysis. It was not possible to guarantee the participants' blinding during the protocol, because all maintained relationships in a patient association called HTLVida.

The primary and secondary endpoints of the study were evaluated at three-time points. The first assessment (Baseline) was performed prior to the entry into the exercise program; the second, evaluated the effect of the program after 12 weeks; the third, evaluated the effect after 24 
weeks. In the first evaluation, the selected subjects received a clarification as to the procedures and objectives of the study, and those who agreed to participate signed the Informed Consent Term.

The main variables of this study were the analysis of posture by $\mathrm{SAPO}^{\oplus 20}$ free software and functional mobility with the TUG, which is a quick and practical functional test based on determining the time needed to get up from an armchair, walk $3 \mathrm{~m}$ forward, turn around, walk back and sit on the chair $^{21}$. The time spent for the execution of the test is timed ${ }^{21}$. We also analyzed, in a complementary way, gait length, gait cycle velocity and joint, knee and ankle angles in the final support phase by $\mathrm{CVMob}^{\circledR}$ free software.

Participants were photographed and filmed with a GoProHeron2 camera, programmed for 120 frames/sec. This camera was connected to a tripod and positioned $2.5 \mathrm{~m}$ from the participant, at a height that corresponded to $50 \%$ of its height and $1.5 \mathrm{~m}$ from the chair used in the TUG in the center of the test path with the aid of a digital chronometer $\left(\right.$ Herweg $\left.^{\circledR}\right)$. The calibration was performed before data collection using a graph paper that contained two black spherical adhesives separated by $20 \mathrm{~cm}$.

The posture measures selected for the study included the vertical alignments of the trunk angle, body angle, knee angle and ankle angle, all according to Macêdo et al. ${ }^{7}$.

The measures selected for gait analysis were gait length, stride length and ankle and knee angles. The phase of the gait cycle selected for analysis of the videos corresponded to the exact moment that the individual passed the camera to minimize possible distortions in the image and not involve moments of acceleration or deceleration. Before analyzing each video, the Go Pro Studio application was used to eliminate the "fisheye" effect in the images. Angular variables investigated bilaterally were maximal joint amplitude of the knee, maximal articular amplitude of the ankle, articular angle in the initial balance, articular angle in the medial balance, articular angle in the medial support and articular angle in the final support.

\section{Intervention procedures}

Intervention details are depicted in Figure 1. The SG participated in 12 weeks of training supervised by a physiotherapist via a face-to-face model, in a group, and at a frequency of twice per week for $50 \mathrm{~min}$. They continued for another 12 weeks, performing the same sequence at home, individually and autonomously. The WG performed the same program for 24 weeks individually at home following guidelines provided by a physiotherapist exclusively at the first meeting. In both the SG and WG, the stretching and muscle strengthening exercises were guided by an illustrated bookguide. Each exercise training session lasted $50 \mathrm{~min}$. The CG received only usual care (medical, psychological, nursing, physiotherapeutic and medication support). The protocol of the bookguide was compiled using theoretical kinetic models developed by physiotherapists and patient-reported needs. It contains illustrated stretching and muscle strengthening exercises for specific muscle groups affected by HAM/TSP.

A monthly meeting evaluated the degree of muscular strength achieved during challenge progression ${ }^{18}$. Upon reaching the cut-off point ( 6 or 7 points on a scale from 0 to 10), the number of repetitions increased up to 15 and then progressed with increasing amplitude and charge. The stretches were sustained statically for $30 \mathrm{sec}$ in two sets for each muscle group. All participants in the SG and WG received the guidebook, elastic bands, a wooden baton and 0.5, 1 and $2 \mathrm{~kg}$ dumbbells for home use.

The exercise sequence described in the guidelines corresponded to (1) stretching of the posterior chain; (2) stretching of hip adductors; (3) stretching of quadriceps and iliopsoas; (4) strengthening of shoulder abductors; (5) strengthening of elbow flexors; (6) wall support; (7) trunk rotation while seated; (8) lateral inclination of trunk; (9) bridge; (10) abduction of hip; (11) adduction of hip; (12) squatting; (13) step training; (14) plantar flexion.

\section{Statistical analysis}

The data were analyzed using SPSS $17.0 \quad(\alpha \leq 0.05$; power=80\%). The independent variable was the group (SG, WG or CG), and the dependent variables were the differences between the intra and intergroup means (normal distribution) or medians (non-normal distribution) at the postural angles (in the TUG) and in the biomechanical measures of gait.

For comparing variables with normal distribution, we used repeated-measured analysis of variance (ANOVA) and

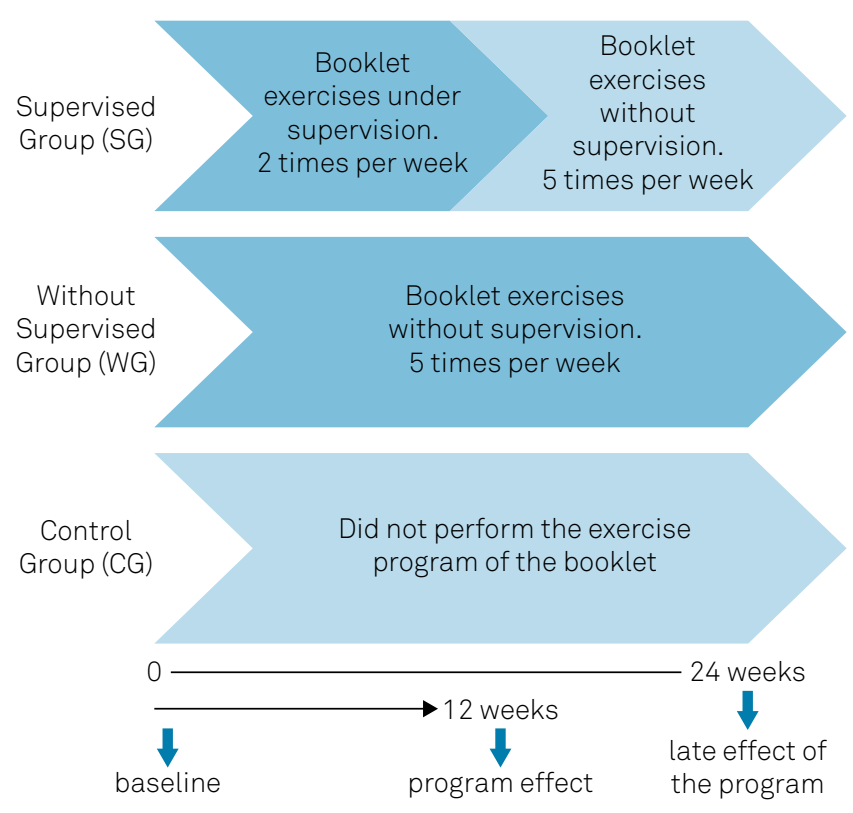

Figure 1. Demonstration of groups and stages of clinical trial evaluation. 
the Bonferroni post hoc test. The Kruskal-Wallis and Friedman tests were used to assess variables that were non-normally distribution. The chi-squared test was used to compare categorical variables. After the clinical trial ended, the same exercise protocol was also offered to the WG and CG through an extension activity.

\section{RESULTS}

Initially, 272 people were contacted by phone. Of these, 72 individuals were not found, 12 did not meet the inclusion criteria and 10 had died. Of the 106 people who agreed to attend the first evaluation, 61 did not agree to participate, and thus 45 participants remained. Of this group, nine were excluded during the period between the first and second evaluation for loss at follow-up. Thirty-six participants completed the protocol (Figure 2), and all their data were analyzed in the intent-to-treat model.
The rate of adherence to the program between the first and second evaluation (participants who started and remained in the study for 12 weeks) was $80 \%$. The rate of adherence to the program between the second and third evaluation was $66.7 \%$. The reasons for these dropouts were diverse (six reported difficulties with transportation, four reported injury secondary to falls and two reported domestic priorities).

There were no differences among groups as to sociodemographic characteristics (Table 1) at baseline.

Evolution of functional mobility measured with the TUG (main outcome) is shown in Figure 3A. Functional mobility improved in the SG and WG when compared to the CG. Furthermore, the best responses were found in the SG.

Comparing the posture evaluations of the three groups at the three-time points (main variables), the body was vertical in the SG between the first and second evaluation in the right (Figure 3A) and left (Figure 3C) profiles; there was also reduced right knee flexion (Figure 3F), followed by right ankle angle elevation (Figure $3 \mathrm{H}$ ). Left knee flexion also increased throughout

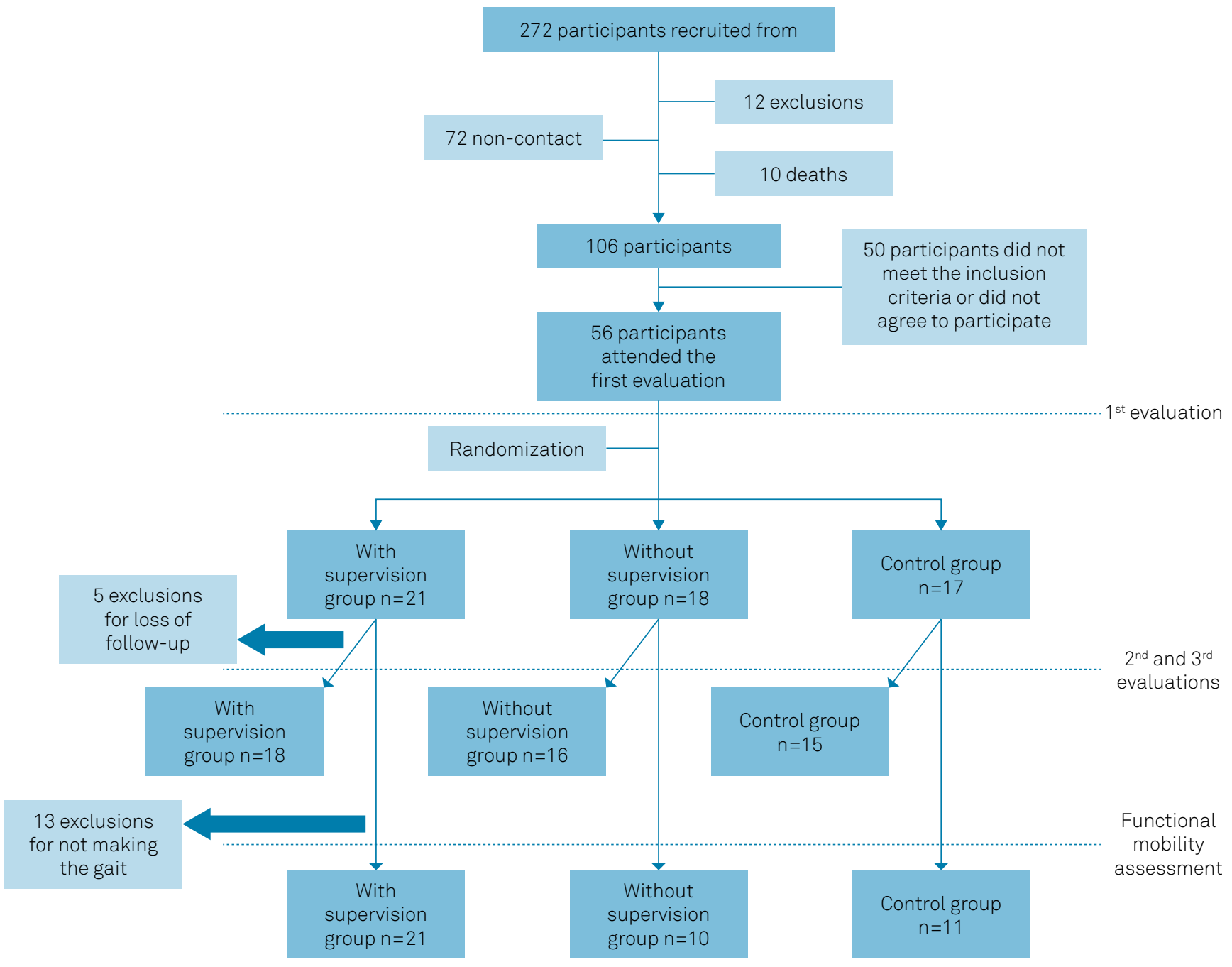

Figure 2. Flowchart for selection of the sample of people with HAM/TSP. 
the program (Figure 3G), the left ankle angle between the first and second evaluation decreased, and this last angle increased at the third evaluation (Figure 3I). The upright posture moved against gravity due to the corrective effect in the postural alignment of body rectification and extension of the right lower limb. In contrast, left knee flexion intensified.

The WG presented trunk verticalization in the right (Figure 3B) and left (Figure 3C3) profiles, in right anterior body hatching (Figure 3D) and in the left profile (Figure $3 \mathrm{E}$ ) between the first and second evaluation (Figure 3F). There were also left (Figure 3G) and right ankle angle reductions (Figure $3 \mathrm{H}$ ). There was an angular reduction in the left ankle between baseline and week 12, and an increase at the third evaluation (between 12 and 24 weeks; Figure 3I).
Despite the trunk verticalization, the WG tended to adopt a previously displaced posture, that was accompanied by a flexor tendency of the lower limbs.

In the CG, body verticalization was observed in the right (Figure 3D) and left (Figure 3E) profiles. The right (Figure 3H) and left (Figure 3I) ankle angles presented the same behavior: between baseline and week 12 there was an angular reduction, and between 12 and 24 weeks there was an angular increase. There was also body displacement towards the vertical throughout the follow-up period, and ankle angle oscillation in the first moment forward and second moment back.

The gait cycle velocity and stride length (secondary variables), presented in Table 2, also exhibited a significant improvement in the SG and WG as compared to the CG.

Table 1. Socio-demographic characteristics of the groups of patients with definite and probable HAM/TSP from the EBMSP HTLV Reference Center, Salvador City/Bahia State, Brazil.

\begin{tabular}{|c|c|c|c|c|}
\hline Total $N=49$ & $\begin{array}{c}S G n=18 \\
n(\%)\end{array}$ & $\begin{array}{c}\text { WG } n=16 \\
n(\%)\end{array}$ & $\begin{array}{c}C G n=15 \\
n(\%)\end{array}$ & $p$-value \\
\hline \multicolumn{5}{|l|}{ Sex } \\
\hline Women & $12(66.7 \%)$ & $11(68.8 \%)$ & $9(60.0 \%)$ & $\star * 0.867$ \\
\hline Age (years old, $X \pm S D$ ) & $55.4 \pm 10.5$ & $53.3 \pm 13.1$ & $49.7 \pm 8.7$ & $\star \star \star 0.331$ \\
\hline \multicolumn{5}{|l|}{ Self-reported skin color } \\
\hline White & 0 & $2(12.5 \%)$ & $1(6.7 \%)$ & \multirow{4}{*}{-} \\
\hline Black & $10(55.6 \%)$ & $5(31.3 \%)$ & $10(66.7 \%)$ & \\
\hline Brown & $8(44.4 \%)$ & $8(50.0 \%)$ & $4(26.7 \%)$ & \\
\hline Yellow & 0 & $1(6.3 \%)$ & 0 & \\
\hline \multicolumn{5}{|l|}{ Schooling* } \\
\hline Illiterate & $1(5.6 \%)$ & 0 & 0 & \multirow{5}{*}{-} \\
\hline Incomplete elementary school & $7(38.9 \%)$ & $5(31.3 \%)$ & $4(26.7 \%)$ & \\
\hline Complete primary education & $4(22.2 \%)$ & $5(31.3 \%)$ & $3(20.0 \%)$ & \\
\hline Complete high school & $3(16.7 \%)$ & $4(25.0 \%)$ & $6(40.0 \%)$ & \\
\hline Complete Higher Education & $3(16.7 \%)$ & $2(12.5 \%)$ & $2(13.3 \%)$ & \\
\hline \multicolumn{5}{|l|}{ Social class-ABEP* } \\
\hline Classes B and C & $11(61.1 \%)$ & $12(75.0 \%)$ & $7(46.7 \%)$ & \multirow{2}{*}{$\star \star 0.270$} \\
\hline Classes $\mathrm{D}$ and $\mathrm{E}$ & $7(38.9 \%)$ & $4(25.0 \%)$ & 8 (53.3\%) & \\
\hline \multicolumn{5}{|l|}{ Marital Status } \\
\hline Married & $5(27.8 \%)$ & $6(37.5 \%)$ & $7(46.7 \%)$ & \multirow{2}{*}{$\star \star 0.532$} \\
\hline Not married & $13(72.2 \%)$ & $10(62.5 \%)$ & 8 (53.3\%) & \\
\hline \multicolumn{5}{|l|}{ Occupation } \\
\hline Active & $10(55.6 \%)$ & $5(31.3 \%)$ & $7(46.7 \%)$ & \multirow{2}{*}{$* * 0.359$} \\
\hline Inactive & $8(44.4 \%)$ & $11(68.8 \%)$ & $8(53.3 \%)$ & \\
\hline
\end{tabular}

SG: Group with supervision; WG: Group without supervision; CG: control group.*Brazilian Economic Classification-ABEP $2013,{ }^{\star *}$ Chi-square, ${ }^{\star \star \star * A n o v a ; ~}<0.05$. 

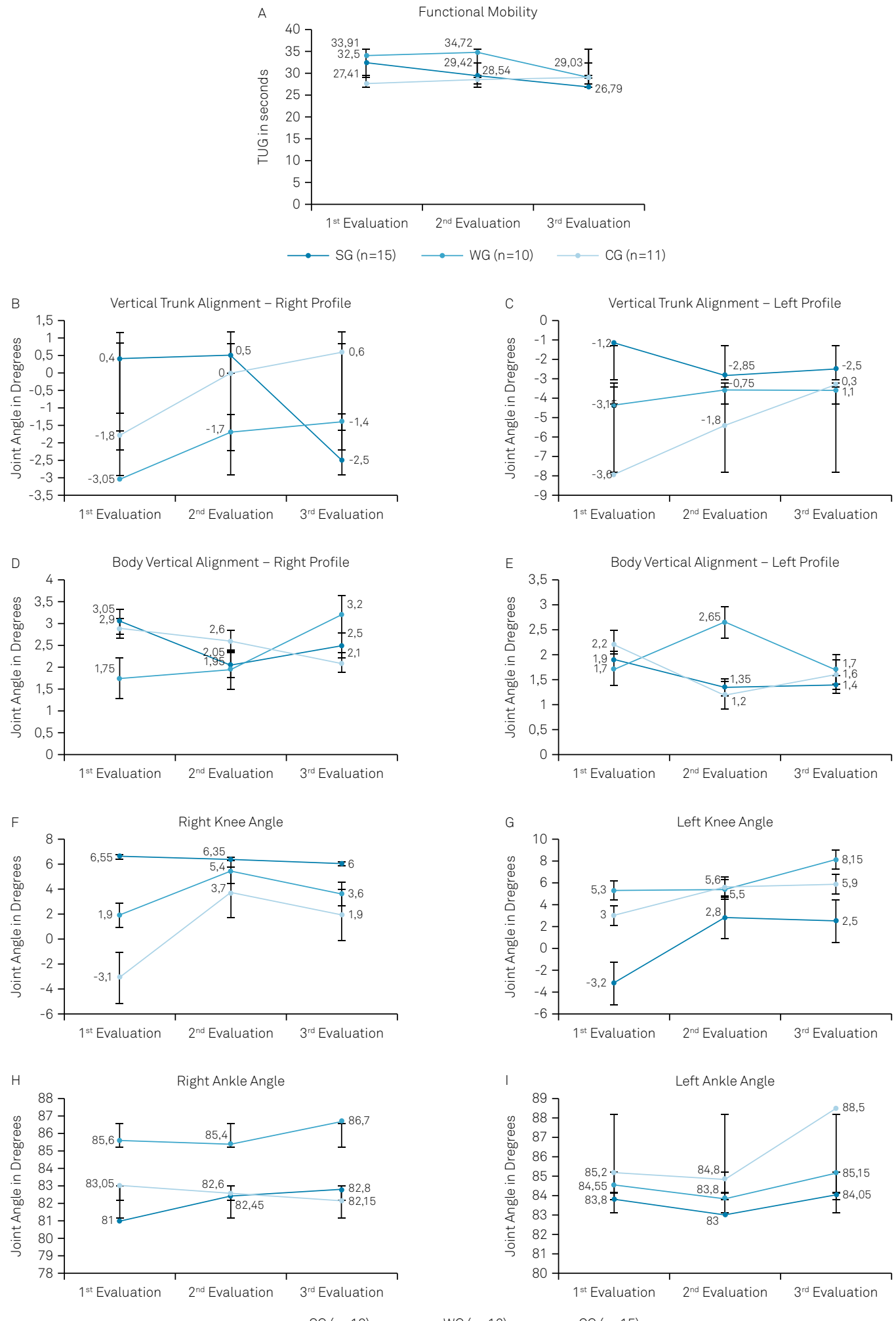

SG: Supervision Group; WG: Without Supervision Group; CG: Control Group; ANOVA Repeated Measures Test and Post Test de Bonferroni; $\alpha \leq 0.05$, statistical power $80 \%$. Bar graphs correspond to standard deviation.

Figure 3. Primary Variables: A — Evolution of the functional mobility measured with the TUG — SG vs.CG ( $p=0.047$; Post Test: $p<0.05) ; W G$ vs.CG ( $p=0.041$; Post Test: $p<0.05) ; S G$ vs. WG ( $p=0.07) ; B$ — Intragroup analysis of the vertical alignment of the trunk in the right profile $(p<0.001) ; C$ - Intragroup analysis of the vertical alignment of the trunk in the left profile $(p=0.013)$; $D$ - Intragroup analyzes of body vertical alignment in the right profile ( $p=0.004) ; E$ — Intragroup analyzes of body vertical alignment in the left profile ( $p=0.027) ; F$ — Intragroup analyzes of the knee angle right ( $p=0.029) ; G$ — Intragroup analyzes of the knee angle left ( $p=0.025) ; \mathrm{H}$ - Intragroup analysis of right angle $(p<0.001) ; \mathrm{I}$ - Intragroup analysis of left angle ( $p<0.001)$ in people with TSP/HAM who participated in a program of home exercises with and without supervision in the $1^{\text {st }}$ evaluation (baseline/ $1^{\text {st }}$ evaluation), after 12 weeks ( $2^{\text {nd }}$ evaluation) and 24 weeks ( $3^{\text {rd }}$ evaluation) of follow-up. 


\section{DISCUSSION}

The results of the present study confirmed that a home exercise program may benefit the posture and functional mobility of individuals with HAM/TSP. Comparisons among the groups suggest that both the SG and WG presented better results than the $\mathrm{CG}$ in the evaluated parameters.

Orthostasis is the preliminary stance for efficient walking. Body segment alignment allows a fluid and precise displacement with less energy expenditure ${ }^{22}$. Knee flexion, as observed in the present sample, predicts compromised gait execution. There are strong correlations between the functional levels of ambulation and the strength of knee extensors and plantar flexors ${ }^{8}$. Due to the complementary nature of the information, the present study opted to analyze both orthostatic posture and functional mobility.

There was better posture alignment in the SG compared to the WG, data that reinforce the need for professionally supervised training to obtain better results with the guidebook. Exercise execution with compensatory patterns can generate maladaptive plasticity in the brain ${ }^{22}$. The CG presented greater verticalization, which can indicate greater difficulty for postural control and increased risk for falls ${ }^{23}$, because a more flexed posture can attempt to lower the center of gravity to improve balance. Future longitudinal studies should evaluate the correlation of the height of the center of gravity with the occurrence of falls to confirm this hypothesis.

Regarding the overall results of the protocol on posture, despite the tendency to assume a more aligned posture by the corrective treatment effect in the SG, there was a concomitant right lower limb extension response with flexion enhancement in the left knee. This discrepancy between the lower limbs may translate into asymmetrical muscle weakness, which involves more complex neuromechanical motor patterns ${ }^{8}$. An electron micrograph study performed in people with HAM/TSP suggests the presence of peripheral neuropathy with asymmetric predominance ${ }^{24}$.

A good preliminary alignment of the body segment improves balance reactions during movements ${ }^{22}$. This concept was reinforced by the TUG results among the groups. Comparison of the TUG averages at the three-time points revealed that the SG responded better than the WG. However, the WG also presented better results when compared to the CG. This finding allows us to affirm that using the guidebook improves functional mobility, even if only with basic guidelines. However, better results are achieved with previous training supervised by a physiotherapist.

Some reasons for the implementation of home exercise programs can be noted, such as restriction of places with rehabilitation services, difficulties with transportation and lack of companions. This modality was applied in other similar chronic conditions with positive impacts on improving functional mobility ${ }^{17,25}$.

Research also revealed that gait cycle velocity and stride length measured during the TUG exhibited differences among groups. Both the SG and WG increased gait speed, although a loss of $0.5 \mathrm{~m} / \mathrm{sec}$ was expected for a 6 -month follow-up period ${ }^{26}$. Previous studies in this population applied gait velocity tests

Table 2. Comparisons of velocities and stride length of individuals with HAM/TSP.

\begin{tabular}{|c|c|c|c|c|c|c|c|c|}
\hline Variable & $\begin{array}{l}\text { Lower } \\
\text { limb }\end{array}$ & $\begin{array}{c}\text { GROUP } \\
\text { Total }(n=36)\end{array}$ & $\begin{array}{c}1^{\text {st }} \text { Evaluation } \\
X(S D)\end{array}$ & $\begin{array}{c}2^{\text {nd }} \text { Evaluation } \\
X(S D)\end{array}$ & $\begin{array}{c}3^{\text {rd }} \text { Evaluation } \\
\text { X (SD) }\end{array}$ & $\begin{array}{c}\text { Intra group } \\
p^{*}\end{array}$ & \multicolumn{2}{|c|}{$\begin{array}{c}\text { Intergroup } \\
p^{*}\end{array}$} \\
\hline \multirow{6}{*}{$\begin{array}{l}\text { Speed of the } \\
\text { gait cycle } \\
\text { (meters/ } \\
\text { seconds) }\end{array}$} & \multirow{3}{*}{ Right } & $S G(n=15)$ & $0.53( \pm 0.28)$ & $0.56( \pm 0.24)$ & $0.59( \pm 0.22)$ & 0.039 & SGvs.CG & 0.002 \\
\hline & & $W G(n=10)$ & $0.49( \pm 0.25)$ & $0.48( \pm 0.26)$ & $0.53( \pm 0.33)$ & 0.042 & SGvs.WG & 0.043 \\
\hline & & $C G(n=11)$ & $0.58( \pm 0.29)$ & $0.58( \pm 0.31)$ & $0.56( \pm 0.28)$ & 0.097 & WGvs.CG & 0.035 \\
\hline & \multirow{3}{*}{ Left } & $S G(n=15)$ & $0.52( \pm 0.29)$ & $0.57( \pm 0.27)$ & $0.59( \pm 0.26)$ & 0.041 & SGvs.CG & 0.019 \\
\hline & & $W G(n=10)$ & $0.48( \pm 0.27)$ & $0.51( \pm 0.31)$ & $0.55( \pm 0.33)$ & 0.041 & SGvs.WG & 0.047 \\
\hline & & $C G(n=11)$ & $0.57( \pm 0.28)$ & $0.58( \pm 0.29)$ & $0.57( \pm 0.24)$ & 0.086 & WGvs.CG & 0.021 \\
\hline \multirow{6}{*}{$\begin{array}{l}\text { Pass Length } \\
\text { (meters) }\end{array}$} & \multirow{3}{*}{ Right } & $S G(n=15)$ & $0.80( \pm 0.26)$ & $0.82( \pm 0.21)$ & $0.85( \pm 0.21)$ & 0.048 & SGvs.CG & 0.044 \\
\hline & & $W G(n=10)$ & $0.78( \pm 0.17)$ & $0.77( \pm 0.23)$ & $0.77( \pm 0.32)$ & 0.092 & SGvs.WG & $>0.05$ \\
\hline & & $C G(n=11)$ & $0.81( \pm 0.26)$ & $0.81( \pm 0.31)$ & $0.80( \pm 0.25)$ & 0.073 & WGvs.CG & $>0.05$ \\
\hline & \multirow{3}{*}{ Left } & $S G(n=15)$ & $0.83( \pm 0.26)$ & $0.82( \pm 0.24)$ & $0.79( \pm 0.24)$ & 0.746 & SGvs.CG & $>0.05$ \\
\hline & & $W G(n=10)$ & $0.74( \pm 0.28)$ & $0.75( \pm 0.28)$ & $0.74( \pm 0.32)$ & 0.732 & SGvs.WG & $>0.05$ \\
\hline & & $C G(n=11)$ & $0.83( \pm 0.25)$ & $0.86( \pm 0.28)$ & $0.85( \pm 0.27)$ & 0.802 & WGvs.CG & $>0.05$ \\
\hline
\end{tabular}

*p-value assigned to $\alpha \leq 0.05$ and power of 80\%. X: mean; SD: standard deviation; THE NEW: Post Test Bonferroni; MID: lower right limb; MIE: left lower limb; SG: Group with supervision; WG: Group without supervision; CG: Control group. 
with the justification of cardiorespiratory fitness assessment, acceleration and cadence ${ }^{23}$. However, this parameter is limited by age, weight, height, muscle strength and presence of spasticity $^{8}$. The TUG is an intriguing tool for monitoring the functional mobility of people with HAM/TSP, because it allows for more complex evaluations of motor control.

Although home-based exercises were already evaluated in people with HAM/TSP ${ }^{14}$, the present study tested this modality with a guidebook developed within an evidence-based clinical practice model (randomized clinical trial). The protocol tested in this context included the best available evidence, clinical experience from physiotherapists, low-cost resources and the patients' own perceptions. Thus, we sought to respond to the model recommended by the WHO for biopsychosocial assistance while simultaneously stimulating autonomy and promoting human dignity ${ }^{27}$.

Notably, gait degradation in individuals with HAM/TSP is known and expected throughout the functional evolution of the progressive disease $e^{5,12,26,28}$. The follow-up losses observed in the present study confirm the adherence difficulty to outpatient programmes. Therefore, it is important to understand that simple maintenance of the condition itself represents a positive outcome, because the condition was expected to worsen in this population at the 6-month followup. Although we had to apply the intention-to-treat method in the statistical analysis, we observed improvement in several parameters evaluated with the home exercises proposed on the guidebook.

The current study has several limitations. It did not analyze the gait in the course recommended for classic biomechanical analyses and cardiorespiratory responses to aerobic exercises, a factor that must be tested in future studies. Moreover, the use of photogrammetry applied to the photographs instead of filming may represent a limitation for the real gains of the assessed angles ${ }^{29}$.

Overall, the proposed exercise protocol developed though evidence-based clinical practice described on a guidebook for home use benefited people with HAM/TSP in the parameters of posture, functional mobility and gait measures. The group that received training supervised by physiotherapists presented the best results, and supervision should be adopted whenever possible. When supervision is impossible, the guidebook should still be performed at home after a meeting with a physiotherapist for basic guidelines.

\section{References}

1. Gessain A, Cassar O. Epidemiological aspects and world distribution of HTLV-1 infection. Front Microbiol. 2012 Nov;3:388. https://doi. org/10.3389/fmicb.2012.00388

2. Dourado I, Alcantara LC, Barreto ML, Teixeira MG, Galvão-Castro B. HTLV-I in the general population of Salvador, Brazil: a city with African ethnic and sociodemographic characteristics. J Acquir Immune Defic Syndr. 2003;34(5):527-31.

3. Santos MM, Pinto MG, Pereira NBU, Santos TC, Sá VHC, Proietti ABFC, et al. Aspectos epidemiológicos da infecção por HTLV-1 e HTLV-2. HTLV. 6. ed. Belo Horizonte: Fundação Hemoninas; 2015.

4. Lepoutre V, Jain P, Quann K, Wigdahl B, Khan ZK. Role of resident CNS cell populations in HTLV-1-associated neuroinflammatory disease. Front Biosci (Landmark Ed). 2009 Jan;14:1152-68. https://doi. $\operatorname{org} / 10.2741 / 3300$

5. Mendes SM, Baptista AF, Sá KN, et al. Pain is highly prevalent in individuals with tropical spastic paraparesis. Health Care. 2013 Jan;1(3):47-53. https://doi.org/10.12966/hc.11.01.2013

6. Santos DN, Santos KOB, Paixão AB, Andrade RCP, Costa DT, Martin DLS, et al. Factors associated with pain in individuals infected by human T-cell lymphotropic virus type 1. Braz J Infect Dis. 2017 Mar/ Apr;21(2):133-9. http://dx.doi.org/10.1016/j.bjid.2016.11.008

7. Macêdo MC, Baptista AF, Castro-Filho BG, Duarte EF, Patrício N, Kruschewsky RA, et al. Postural profile of individuals with HAM/ TSP. Braz J Med Human Health. 2013;2(1):99-110. http://dx.doi. org/10.17267/2317-3386 bjmhh.v1i2.168

8. Franzoi AC, Araújo AQC. Disability and determinants of gait performance in tropical spastic paraparesis/HTLV-I associated myelopathy (HAM/TSP). Spinal Cord. 2007 Jan;45(1):64-68. https:// doi.org/10.1038/sj.sc.3101919

9. Sá KN, Patrício NA, Conceição CS, Luz C, Vivas J. A proposal for biomechanical evaluation of balance in HTLV-1 individuals. JJ Physical Rehab Med. 2016;2(1):023.
10. Champs APS, Passos VMA, Barreto SM, Vaz LS, Ribas JGR. HTLV I Myelopathy prognostic factors for total gait disability in patients with human T cell lymphotropic virus I associated myelopathy: a 12-year follow-up study. Epidemiol. 2013;3:131. https://doi. org/10.4172/2161-1165.1000131

11. Caiafa RC, Orsini M, Felicio LR, Puccioni-Sohler M. Muscular weakness represents the main limiting factor of walk, functional independence and quality of life of myelopathy patients associated to HTLV-1. Arq Neuropsiquiatr. 2016;74(4):280-6. http://dx.doi. org/10.1590/0004-282X20160019

12. Livramento DF, Duran LS, Galvão-Castro B, Sá KN. Efeito de exercícios de Pilates na postura de portadores de HAM/TSP associado ao HTLV1. Fisioter Pesqui. 2012;2(1):13-23. http://dx.doi.org/10.17267/22382704rpf.v2i1.82

13. Borges J, Baptista AF, Santana N, Souza I, Kruschewsky RA, Galvão-Castro B, et al. Pilates exercises improve low back pain and quality of life in patients with HTLV-1 virus: a randomized crossover clinical trial.J Bodyw Mov Ther. 2014 Jan;18(1):68-74. https://doi. org/10.1016/j.jbmt.2013.05.010

14. Facchinetti LD, Araújo AQ, Silvia MT, Leite ACC, Azevedo MF, Chequer GL, et al. Home-based exercise program in TSP/HAM individuals: a feasibility and effectiveness study. Arq Neuropsiquiatr. 2017 Apr;75(4):221-7. http://dx.doi.org/10.1590/0004-282x20170022

15. Britto VL, Correa R, Vincent MB. Proprioceptive neuromuscular facilitation in HTLV-I-associated myelopathy/tropical spastic paraparesis. Rev Soc Bras Med Trop. $2014 \mathrm{Jan} / F e b ; 47(1): 24-9$. http:// dx.doi.org/10.1590/0037-8682-0245-2013

16. Figueiredo Neto I, Mendonça RP, Nascimento CA, Mendes SMD, Sá KN. Fortalecimento muscular em pacientes com HTLV-I e sua influência no desempenho funcional: um estudo piloto. Fisioter Pesqui. 2012;2(2):143-55. http://dx.doi.org/10.17267/2238-2704rpf. v2i2.96 
17. Hill KD, LoGiudice D, Lautenschlager NT, Said CM, Dodd KJ, Suttanon P. Effectiveness of balance training exercise in people with mild to moderate severity Alzheimer's disease: protocol for a randomised trial. BMC Geriatr. 2009 Jul;9:29. https://doi.org/10.1186/1471-2318-9-29

18. Castro-Costa CM, Araújo AQ, Barreto MM, Takayanagui OM, Sohler MP, da Silva EL, et al. Proposal for diagnostic criteria of tropical spastic paraparesis/HTLV-I-associated myelopathy (TSP/HAM). AIDS Res Hum Retroviruses. 2006 Oct;22(10):931-5. https://doi. org/10.1089/aid.2006.22.931

19. Laboratório de Epidemiologia e Estatística. Available from: http:// www.lee.dante.br.

20. SAPO - Software para avaliação postural. Available from: http:// demotu.org/sapo2/SAPOdoc.pdf.

21. Dutra MC, Cabral ALL, Carvalho GA. Tradução para o português e validação do Teste Timed Up And Go. Rev Interfaces. 2016;3(9):81-8.

22. Shumway-Cook A, Woollacott MH. Controle postural normal. In: Shumway-Cook A, Woollacott MH, eds. Controle Motor: teoria e aplicações práticas. 3. ed. São Paulo: Manole; 2010. p.153-78.

23. Neumann DA. Cinesiologia do Aparelho Musculoesquelético. 2. ed. Rio de Janeiro: Elsevier; 2011.

24. Wucherpfennig KW, Strominger JL. Molecular mimicry in T cellmediated autoimmunity: viral peptides activate human $T$ cell clones specific for myelin basic protein. Cell. 1995;80(5):695-705. https:// doi.org/10.1016/0092-8674(95)90348-8

25. Stack E, Roberts H, Ashburn A. The PIT: SToP trial-A feasibility randomised controlled trial of home-based physiotherapy for people with Parkinson's disease using video-based measures to preserve assessor blinding. Parkinsons Dis. 2012;2012:360231. https://doi. org/10.1155/2012/360231

26. Adonis A, Taylor GP. Assessing walking ability in people with HTLV1-associated myelopathy using the 10 meter timed walk and the 6 minute walk test. PLoS One. 2016 Jun; 11(6):e0157132. https://doi. org/10.1371/journal.pone.0157132

27. World Health Organization. World report on disability. Geneva: The World Bank; 2011.

28. Martin F, Fedina A, Youshya S, Taylor GP. A 15 year prospective longitudinal study of disease progression in patients with HTLV-1 associated myelopathy in the UK. J Neurol Neurosurg Psychiatry. 2010 Dec;81(12):1336-40. https://doi.org/10.1136/jnnp.2009.1

29. Patrício NA, Macêdo MC, Miranda GV, Peña N, Baptista AF, Sá KN. Postural investigation in individuals with human T cell lymphotropic virus-1-associated myelopathy/Tropical spastic paraparesis. J Clin Eng. 2017 Jan;42(3):136-41. https://doi.org/10.1097/ JCE.000000000000022 